\title{
SYRIACA \\ ET VARIA ORIENTALIA
}

\section{Miscellanea Orientalia Christiana / Восточнохрис-}

тианское разнообразие, редакторы Николай СЕЛЕЗНЕВ И ЮРИЙ АРЖАНОВ, Москва: ИВКА РГГУ, Пробел-2000, 2014, 408 с. ISBN 978-5-98604-419-4.

[Miscellanea Orientalia Christiana, ed. by Nikolai SELEZNYOV, Yury ARZHANOV, Moscow, 2014, 408 p.]

Originally planned for the fourth volume dedicated to the Christian Orient of the French-Russian periodical Simvol, ${ }^{1}$ the present volume was eventually published in non-serial form under the auspices of the Russian State University for the Humanities (Moscow) and the Seminar für Orientalistik und Islamwissenschaft at Ruhr-Universtität (Bochum). It is subdivided into five sections: Syriaca, Caucasiana, Coptica \& Aethiopica, Turcica, and Arabica. All contributions are in Russian and address the wide audience of Russian-speakers who are interested in the Christian Orient. However, most of the contributions are of international scholarly importance. Without reproducing the whole list of contents (provided by the editors in Russian and German), I would especially recommend the following:

Yulia FURMAN, The first day of Creation and "first natures" in the History of the Temporal World by John bar Penkaye (p. 9-25) - with a critical edition of the previously unpublished text (cf. the current author's publication in the present volume of $S c r$ ).

Yury ARZHANOv, Aristotle's Physica in the Syriac school (p. 5891) - with a publication of some previously unpublished short fragments in Syriac,

Nikolai SELEZNYOV, Seven canons and nine signs: The doctrinal section of John bar Zo'bi's liturgical poem 'Explanation of the Mysteries' (p. 92-127) - with a critical edition of the corresponding section of the poem (now included in Seleznyov's own complete critical edition of the poem).

(1) Cf. Simvol, 55 (2009), 58 (2010), 61 (2012); reviewed in Scr, 7-8 (20112012), pp. 367-369 and 9 (2013), pp. 440-441. 
Igor DORFMANN-LAZAREV, Return to the Cave of the Nativity: the memory of the first created humanity in the Armenian "Writing about the Childhood of the Lord" and related sources (p. 149-184), which is a "substantially enlarged" version of the author's 2013 paper that was published in German.

Tamara PATARIDZE, Do translations from Syriac into Georgian exist? (p. 185-206).

Dmitrij BuMAZHNOV, Unknown Christian parallels to the Muslim legend of the dialog between Jesus and the scull (p. 248-257).

Alexey GUDKOV, The Ethiopian Scribe (with reference to miniature painting in the $14^{\text {th }}-18^{\text {th }}$ centuries and field research from the late $20^{\text {th }}$ early $21^{\text {st }}$ century) (p. 258-284).

Anton PRITULA, Syroturcica: A bilingual poem from the Mongol period (p. 287-308) (editio princeps).

Alexander TREIGER, The Christology of the Letter from the People of Cyprus (p. 311-347) - with an inquiry into the history of the Arabic text and its manuscript tradition; according to the Treiger, this Christology is Nestorian, even though the anonymous Christian author reworked a well-known Melkite treatise. This paper is also published in English in a slightly different version. ${ }^{2}$

Nikolai SELEZNYOV, Passio secundum Ibn al-Akfani: the doctrine of Christ's Passions on the Cross in traditional Muslim religious studies (p. 348-358).

Konstantin PANTSCHENKO, To recall the past: Patriarch Macarius of Antioch as historian (p. 359-384). - A detailed study based on an important but unpublished manuscript.

Dmitry MOROZOV, A new book on the early history of the text of the Arabic Bible. [Review of Sidney H. Griffith, The Bible in Arabic: The Scriptures of the "People of the Book" in the Language of Islam] (p. 385401). - A valuable and detailed discussion.

(2) Journal of Eastern Christian Studies, 65 (2013), pp. 21-48. 
H. H. Селе3нев, Pax Christiana et Pax Islamica. И3 истории межконфессиональных связей на средневековом Ближнем Востоке (Orientalia et Classica. Труды Института восточных культур и античности, XLV), Москва, 2014, 268 с.

ISBN 978-5-7281-1594-6

[N. N. SEleznyov, Pax Christiana et Pax Islamica. On the History of Interconfessional Relations in the Medieval Near East (Orientalia et Classica. Papers of the Institute of Oriental and Classical Studies, XLV), Moscow, 2014, p. 268 (in Russian, with a Table of contents in English).]

The book contains ten articles by Nikolai Seleznyov (previously published in various periodicals) introduced by a foreword. They are as follows:

Heraclius and Ishō'yahb II: An Eastern Episode in the 'Ecumenical' Project of the Byzantine Emperor. - The episode under discussion is the concelebration by Nestorian catholicos with Byzantine clergy in 628 in Aleppo, when the emperor Heraclius took communion from the hands of Ishō'yahb. I think the author interprets adequately the data from Nestorian historiography. Some historiographers have accentuated the homonymity of the traditional Nestorian teaching about one will in Christ with the monothelite doctrine of Heraclius and represented the whole episode as the adoption of their faith by the Byzantine emperor; this, in turn, has contributed to the high estimation of Heraclius in post-Arab historiography, a feature which the Nestorians share with other non-Melkite Oriental Christians.

The Age of the Caliphate. The Epistle on Unity by a Baghdad Melkite in a Coptic Encyclopedist's Arabic Theological Summa. Contains a Russian translation of a lost treatise by the tenth-century Melkite theologian Nazîf ibn Yumn about the profound theological unity of different Christian confessions.

A West Syrian Clerk from Arfād and the Metropolitan of Jerusalem of the Church of the East: The Book of the Concordance of Faith and Its Recension in Garshūnī. - Contains a critical edition of this recension of 'Alī ibn Dāwud al-Arfādī's treatise on the substantial 
identity of different Christian confessions. ${ }^{3}$ In addition, Seleznyov quotes (in Arabic and in Russian tr.) the previously unpublished witness of the $13^{\text {th }}$-cent. Coptic writer Butrūus al-Ğamīl (acc. to Vat. ar. 74) that the Armenians perform the sign of the Cross with two fingers (p. 102, fn. 176). The Syriac characters of the Garshūnī text are preserved. Some parts of the study have previously been published in English as "'Elias Geveri of Damascus' in Russian Studies of Church History: A Witness to the Two-Finger Sign of the Cross in a Medieval Treatise on Denominations of Syrian Christianity."4

The three following essays present annotated Russian translations of their corresponding Arabic treatises:

A Nestorian Philosopher in the Copto-Arabic Literature: Ibn alTayyib Retold by Ibn al-'Assāl;

Hunayn ibn Ishāa. "The Most Honourable, the Unique, Knowledgeable, Respectable, Wise Man, Philosopher, and Physician" (tr. of Hiunayn ibn Ishāà's On How to Discern the Truth of Religion);

A Chronicle or a Historical Romance? The Reign of Zeno and Events in the East according to The Blessed Compendium of alMakīn ibn al-'Amīd.

However, in the case of the latter, the translation is prepared on the basis of several unpublished manuscripts, and so could be considered as preparatory work for a future critical edition.

Interpretations of the Origins of the Designation "Jacobite" by Medieval Egyptian Arabic Authors. - This is an enlarged version of the paper previously published in English: "Jacobs and Jacobites: The Syrian origins of the name and its Egyptian Arabic interpretations" [Scr 9 (2013), pp. 382-398]. Two important testimonies are added: that of Ibn Haldūn who refers to al-Makīn ibn al-'Amīd explaining the term with the pre-monastic name of Dioscorus (pp. 163-164) and that of aṣ-Șanhāğì called al-Qarāfì (1228-1285) who identifies the mysterious Jacob with Jacob of Sarug (pp. 167-168).

Christian Communities of the East as Witnessed by Leonhart Rauwolf. - The relevant part of the travelogue published in German in 1583 (the travel itself took place in 1573-1576) is partially para-

(3) Has been known since the $18^{\text {th }}$ century but previously published by Seleznyov himself in Simvol, 58 (2010) with a study in Russian. According to G. Troupeau the treatise dates from the $11^{\text {th }}$ cent., however Seleznyov expresses some doubts about such a late dating.

(4) Scr, 9 (2013), pp. 366-381. 
phrased and partially translated into Russian. The whole book by Rauwolf was published in English translation in 1738 but has since been generally overlooked by specialists in the Christian Orient. Rauwolf's observations were made in Jerusalem.

The last article Franks to Nubians: An Arabic Treatise on the Peculiarities of Different Christian Denominations by a Coptic Author (Mingana Chr. Arab. 71) has previously been published in English as "Franks and Eastern Christian Communities: A Survey of Their Beliefs and Customs by an Arabic-Speaking Coptic Author (MS Mingana Chr. Arab. 71)." 5

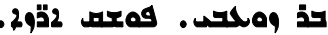

Н. Н. СЕЛЕЗНЕв, Йо̄ханна̄н Бар Зо̄`бй и его «Истодкование таин». Критический текст, перевод, исследование, Москва: ИВКА РГГУ, Пробел-2000, 2014, 224 c. ISBN 978-5-98604-444-6

[Nikolai N. SELEZNYOV, Yōḥannān Bar Zō’b̄̄ and His "Explanation of the Mysteries." Critical Text, Russian Translation from Syriac, and Investigation, Moscow, 2014, 224 p.]

This important metric explanation of the Eucharistic liturgy of the Church of the East (dating from the early $13^{\text {th }}$ cent. or slightly earlier) has been known to the scholarly world since the nineteenth century but so far has never been published in its entirety. The complete French (1966) and English (1992) translations of the work are both based on the same defective manuscript from the year 1867. The present critical edition, however, is based on nine manuscripts mostly from the eighteenth century (although the earliest manuscript is from the sixteenth century, and one manuscript dates from 1687).

Among the problems discussed in the short introduction (pp. 528) two were solved by the editor himself as follows. He argues for the direct dependency of Yōḥannān Bar Zō'bī on a prosaic seventhcentury liturgical commentary by Gabriel Qațraya (pp. 14-15, pace W. de Vries who thought that this dependency had been mediated by the commentary by Abraham Bar Lipēh). Moreover, Seleznyov puts forward the hypothesis that the liturgy that Bar Z $\bar{o}^{\prime}$ bì had in mind

(5) Христианский Восток 6 (XII) (2013), pp. 150-161. 
was that of Addai and Mari, despite the fact that his commentary includes the institutional words in the anaphora (pp. 15-16). Indeed, Bar Zō'bī's predecessors (beginning with Pseudo-Narsai and PseudoGregory of Arbela) did include the Institutio in their commentaries because they kept in mind the two other Eucharistic liturgies of the Church of the East, those of Nestorius and Theodore of Mopsuestia. This fact could have contributed towards the formation of the pattern of liturgical commentary which requires quotation of the institutional words. However, in general, the commentary by Bar Z $\bar{o}^{\prime}$ bì looks as if it follows the Addai and Mari rather than the two other Eastern anaphoras. Seleznyov's hypothesis does agree with my own feelings, but we have to take into account that a detailed study of the commentary is still a task for the future.

Seleznyov provides a useful glossary of liturgical terms (pp. 207210), but this is not enough for being able to follow the liturgical commentary if you do not already possess a mental outline of the East Syrian Eucharistic liturgy. For instance, to readers accustomed to the Byzantine rite, it would be rather difficult to notice that "the prayer that Christ gave to his Church" (line 201, p. 58/59 txt/tr.) is the Pater that is to be sung in full before the anaphora.

The critical edition of such an important work is a serious achievement in the field of historical liturgy. The scholarly community will certainly be grateful to Nikolai Seleznyov.

B. Lourié

Saint Petersburg State University of Aerospace Instrumentation

\section{DAS RUSSISCH-DEUTSCHE SEMINAR ,SIMON LÜDWIGOWITSCH FRANK: DER DEUTSCHE KONTEXT DER RUSSISCHEN PHILOSOPHIE“}

Am 10-11. Oktober 2013 hat das russisch-deutsche Seminar an der Staatlichen Universität St. Petersburg stattgefunden. Das Seminar war russischem Religionsphilosophen Simon Lüdwigowitsch Frank (1877-1950) gewidmet. Das Schicksal Franks war nicht nur mit Russland, sondern auch mit Deutschland verbunden. Er lernte zuerst an 